\title{
A note on the effect of feeding local forages to commercial layers on egg production and yolk colour
}

\author{
A. Téguia \\ Department of Animal Science, University of Dschang \\ P.O. Box 70. Dschang, Cameroon \\ (Reccived 20 September 1999; accepted 8 May 2000)
}

\begin{abstract}
The effect of feeding Arachis glabrata. Leucaena lencocephala, Calliandra calothyrsus or Desmodium spp. leaves to commercial layer on egg production and yolk colour was compared with the effect of feeding an artificial yolk pigmentor (Carophyl (B)). Percent hen-day production averaging 77.4 and $74.7 \%$, respectively for hens fed on Desmoditum spp. and Leucaena leucocephala leaves, were significantly $(\mathrm{P}<0.05)$ higher than egg production in the control group. No significant difference was recorded among treatment groups for shell thickness. Yolk colour in groups fed forage leaves ranges between 6.76 and 9.83 and was significantly better than in control group (2.35). It was concluded that any of the studied forage leaves could be used to supply xanthophyll to commercial laycrs with no detrimental effect on egg production and quality.
\end{abstract}

KEY WORDS: layers, egg production, yolk colour, forage leaves, artificial pigmentor

\section{INTRODUCTION}

One of the major problems facing African table eggs producers is that of convincing the local consumer that eggs produced in modern poultry farms are of comparable quality with eggs from village scavenging hens. In general the local reference is the size of the egg usually around 35-45 $\mathrm{g}$ and particularly the colour of the yolk that must be dark yellow. In many countries, carotenoid pigments improving the colour of the egg yolk as well as the shanks and beaks of laycrs are found in ycllow maizc, lucerne meal, maize gluten meal (Leeson and Summers, 1997) and artificial pigmentors. According to Sunde (1992) the sales of pigmentors in the USA amount to about $\$ 150$ millions/year while in Europe some $\$ 100$ 
millions are spent yearly. In Tropical Africa however, lucerne and maize gluten meals are not readily available and maize is the main source of xanthophylls. As maize used by local feed manufacturers is mainly white and not usually very rich in pro-vitamin A, the solution to better egg yolk colouring is the utilisation of artificial pigments. Artificial pigments are usually expensive and therefore out of reach for most of those farmers who make their own feed from basic ingredients. However, it could be possible to include some locally produced forages to improve the xanthophyll content of layer fecds without increasing the cost of feeding or reducing the production level. In addition, reports by Téguia et al. (1993) had shown that adding small amount of leaves to broiler diet could have a positive effect on production.

Leaves of perennial peanuts (Arachis glabrata) are widely used for ruminant nutrition (Moore et al., 1981) but may have a value for poultry, particularly for egg yolk colouring and additional protein. Téguia et al. (1997) however reported that weight gain by broiler chickens was depressed and feed conversion ratio was increased when perennial peanut replaced above $200 \mathrm{~g}$ maize $\mathrm{kg}^{-1}$. Leucaena leucocephala and Calliandra calothyrsus introduced some few years ago as a feed supplement for ruminants during the dry season in the Western Highlands of Cameroon are known to be rich in carotenc. Desmodium spp. are widely spread natural legume found in the country, particularly Desmodium uncinatum and Desmodium inturtum.

The objective of the present work was to study the effect of adding Arachis glabrata Benth, Leucaena leucocephala, Calliandra calothyrsus or Desmodium spp. to layer feed on egg quality and production of commercial layers.

\section{MATERIAL AND METHODS}

Animals

One hundred and eighty 53-week old Bridomat layers were randomly distributed to 30 groups of 6 birds housed in pairs in Californian type cages of the University Experimental Farm. Birds were immunised against Newcastle disease, infectious bronchitis, Gumboro discase, cholera and fowl pox.

Feeding

The experimental farm layer feed was formulated to contain (\%): crude protein 17; crude fibre 3.5; Ca 3.5; P 0.45 and $2641 \mathrm{kcal} \mathrm{ME} / \mathrm{kg}$.

Fresh green lcaves of Arachis glabrata, Leucaena leucocephala, Calliandra calothyrsus were collected daily from the University of Dschang Experimental 
Farm while a mixture of fresh Desmodium inurtum and Desmodium uncinatum leaves were collected daily from the farm surroundings. No particular attention was given to the age of leaves. Samples of forage species were oven dricd at $50^{\circ} \mathrm{C}$ for $48 \mathrm{~h}$ and analysed for crude protein, crude fibre, crude fat according to AOAC (1980), dry matter $\left(105^{\circ} \mathrm{C}\right.$ for $\left.24 \mathrm{~h}\right)$ and ash $\left(500^{\circ} \mathrm{C}\right.$ over night). All the leaves were finely cut into very small pieces using a knife.

Five groups of 36 birds were given in each experimental or control diets. Birds in control group were given per hen daily $167 \mathrm{~g}$ of layer feed containing $0.1 \mathrm{~g}$ Carophyl $/ \mathrm{kg}$, while birds in experimental groups were given $153 \mathrm{~g}$ of layer diet and $14 \mathrm{~g}$ of forage leaves per hen per day.

\section{Data collection}

During a six-week experimental period, data were collected on daily egg production and egg weight. After every 7-day period, 2 cggs per replicate for a total of 12 eggs per treatment were randomly selected, individually marked, refrigerated at $+4^{\circ} \mathrm{C}$ for $24 \mathrm{~b}$ then used for egg quality study. Each egg was weighed to the nearest $0.1 \mathrm{~g}$ using an electronic Mettler PE 160 scale and broken for the following measurements:

- yolk colour using a Roche Yolk Colour Fan graduated from 1 to 15

- albumen height using Haugh unit according to USDA system where eggs are ranked $A A$ for values equal or above 72 , A for values between 60 and 71 and $B$ for values from $31-59$

- shell thickness to the nearest $0.01 \mathrm{~mm}$ at 2 different points of the equator of the egg using a Ames 25 M-5 micrometer (Walthman, Mass, USA) after the shell had been thoroughly washed then oven dried at $40^{\circ} \mathrm{C}$ for $24 \mathrm{~h}$

- shell weight after the drying using the electronic scale.

The percent hen-day egg production and the $\%$ egg shell were then calculated.

Data were analysed using a completely randomized design with 5 treatments replicated 6 times each. The least significant difference test was used for mean separation in case of significant difference (Stecl and Torric, 1980).

\section{RESULTS AND DISCUSSION}

Table 1 summarises the chemical composition of the forage leaves. The percent of DM was lowest for Desmodium spp. and highest for Leucaena leucocephala. Except for Calliandra calothyrsus leaves, the $\mathrm{CP}$ content of all forages was above $20 \%$ of DM. The crude fibre content of Arachis glabrata was almost twice that of 
the other leaves whose values were bellow $16 \%$. The highest crude fat content was recorded with Calliandra calothyrsus and the lowest with Arachis glabrata. The wide variations observed in the chemical composition of samples confirmed earlier report by Téguia et al. (1999) for the browse specics. The values obtained for Desmodium spp. leaves were in the range reported by Skerman (1982). The N content of Leucaena leucocephala and Calliandra calothyrsus was respectively lower and higher than values previously reported by Téguia et al. (1999) for samples from the same farm plots. The difference may be attributed to the age of leaves.

The data of cgg production are given in Table 2. Hens fed Desmodium or Leucaena leucocephala leaves had significantly $(\mathrm{P}<0.05)$ higher rate of egg production than those fed the control diet. With $73 \%$ hen-day egg production, birds on Arachis glabrata ration were comparable with those on Leucaena leucocephala and Calliandra calothyrsus diets on one hand and to the control group on the other. For average cgg weight, birds recciving Calliandra calothyrsus produced significantly $(\mathrm{P}<0.05)$ lighter eggs than those of the control group, however, comparable with eggs from all the other groups fed on green leaves. There was no significant $(\mathrm{P}>0.05)$ difference between the control group and the groups fed either Arachis glabrata, Leucaena leucocephala or Desmodium spp. leaves for average egg weight (Table 2).

TABLE 1

Chemical composition of Arachis glabrata, Leucaena leucocephala, Calliandra calothyrsus and Desmodium spp. leaves, \% DM

\begin{tabular}{lccccc}
\hline Leaves & $\begin{array}{c}\text { Dry } \\
\text { matter }\end{array}$ & $\begin{array}{c}\text { Crude } \\
\text { protein }\end{array}$ & Ash & $\begin{array}{c}\text { Crude } \\
\text { fibre }\end{array}$ & $\begin{array}{c}\text { Crude } \\
\text { fat }\end{array}$ \\
\hline Arachis glabrata & 84.08 & 21.22 & 10.44 & 27.42 & 3.41 \\
Calliandra calothyrsus & 84.91 & 18.81 & 9.27 & 12.49 & 5.28 \\
Leucaena leucocephala & 90.90 & 23.01 & 8.00 & 15.80 & 4.01 \\
Desmodium spp. & 54.10 & 24.14 & 6.68 & 14.40 & 5.00 \\
\hline
\end{tabular}

TABLE 2

Egg production and characteristics of eggs from laying hens fed Arachis glabrata, Leucaena leucocephala, Calliandra calothyrsus and Desmodium spp. leaves

\begin{tabular}{|c|c|c|c|c|c|}
\hline Treatments & $\begin{array}{c}\text { Average egg } \\
\text { weight, g }\end{array}$ & $\begin{array}{l}\text { \% hen day } \\
\text { production }\end{array}$ & $\begin{array}{c}\text { Egg shell } \\
\%\end{array}$ & $\begin{array}{l}\text { Shell thickness } \\
\text { mm }\end{array}$ & Yolk colour \\
\hline Control & $65.9 \pm 3.6^{\mathrm{a}}$ & $70.1 \pm 9.8^{c}$ & $8.88 \pm 0.33^{n}$ & 0.368 & $2.35 \pm 0.0^{\mathrm{J}}$ \\
\hline T] (Arachis) & $65.1 \pm 4.6^{\mathrm{ab}}$ & $73.0 \pm 11.2^{\mathrm{bx}}$ & $8.97 \pm 0.52^{\mathrm{ihh}}$ & $0.367 \pm 0.01^{1}$ & $6.76 \pm 0.5$ \\
\hline $\mathrm{T} 2$ (Leutaena) & $65.3 \pm 3.3^{\text {uh }}$ & $74.8 \pm 11.0^{\mathrm{sh}}$ & $8.84 \pm 0.18^{\mathrm{h}}$ & $0.364 \pm 0.01^{a}$ & $9.83 \pm 0.0^{\mathrm{a}}$ \\
\hline T3 (Calliandra) & $64.1 \pm 2.6^{h}$ & $73.5 \pm 2.7^{\mathrm{hc}}$ & $9.11 \pm 0.27$ & $0.368 \pm 0.01^{\circ}$ & $9.09 \pm 0.5^{\text {th }}$ \\
\hline $\mathrm{T} 4$ (Desmoditum) & $65.1 \pm 2.3^{\mathrm{ath}}$ & $77.4 \pm 7.6^{6}$ & $8.90 \pm 0.73^{\mathrm{ah}}$ & $0.363 \pm 0.73^{\mathrm{ihh}}$ & $8.64 \pm 0.7^{\text {ah }}$ \\
\hline
\end{tabular}

atre means with same letter in the same column are not significantly different at $\mathrm{P}<0.05$ 
The increase in egg production in the groups of hens fed leaves as compared with the control group may be related to the effects of additional nutrients such as proteins contained in the forages. Reports of Téguia ct al. $(1993,1997)$ had shown that adding small amounts of leaves to broiler chicken diet could have a positive effect on production parameters. Although feeding of leaves to layers seemed to have a detrimental effect on egg weight, the total cgg mass benefited from adding leaves to the diets.

All the eggs produced during this experiment had Haugh unit values above 72 and were therefore ranked AA according to the USDA (1984) standards. For yolk colour, eggs from all the birds fed forage leaves had significantly $(\mathrm{P}<0.05)$ higher pigmentation values than the control group of birds receiving the artificial pigmentor. Among the leaves, Leucaena leucocephala ranked highest with an average value of 9 on a scale of 1 to 15 but comparable to Calliandra calolthyrsus and Arachis glabrata ranked lowest with an average value of about 7 (Table 2). The difference observed between hens fed different types of leaves may be attributed to a more efficient absorption and deposition of oxycarotenoids from Leucaena and Calliandra (Hencken, 1992).

Values of shell thickness were very similar for all treatments as the absolute value of differences among them were less than $10^{-2} \mathrm{~mm}$. Average percent egg shell of eggs from hens receiving the control ration or Leucaena leucocephala was significantly $(\mathrm{P}<0.05)$ lower than that of eggs from hens fed on Calliandra leucocephala leaves. However, there was no significant $(\mathrm{P}>0.05)$ difference between Arachis glabrata, Calliandra calothyrsus and Desmodium spp. for percent egg shell. The control diet, and the diets with Arachis, Leucaena or Desmodium leaves were also comparable for percent egg shell. The percent egg shell in all the groups was lower than the 11\% suggested by North (1984) for a newly laid egg, but this could be related to the age of layers as the proportion of shell material deposited decrease with the age of birds.

\section{CONCLUSIONS}

The results suggest that Leucaena and Desmodium lcaves significantly improved percent hen day production and any of the studied forage leaves could be used to supply xanthophyll to commercial layers and that with these dietary levels, there was no detrimental effect on egg quality. 


\section{REFERENCES}

Hencken H., 1992. Chemical and physiologicat behavior of fecd carotenoids and their effects on pigmentation. Poultry Sci. 71, 711-717

Leeson S., Summers J.D., 1997. Commercial Poultry Nutrition. 2nd Edition. University Books, Guclph. Ontario (Canada), pp. 350

Moore J.E., Ellis G.L., Rios L. Koger M., 1981. Estimates of the voluntary intake and nutrient digestibility of bahiagrass pasture by grazing stecrs. Soil Crop Sci. Soc. Fla. Proc. 29, 1-175

North M.O., 1984. Commercial Chicken Production Manual. 3rd Edition. AVI Publishing Company Inc., Westport, Connecticut (USA)

Skerman P.J., 1982. Les légumineuses fourragères tropicales. Collection FAO: Productions Végétales et Protections des Plantes, N². FAO, Rome, pp. 666

Steel R.G.D., Torrie J.H., 1980. Principles and Procedures of Statistics. 2nd Edition. McGraw-Hill, New York, pp. 633

Sunde M.L., 1992. Symposium: The scientific way to pigment poultry products. Introduction to the symposium. Poultry Sci. 71. 709-710

Téguia A., Njwe R.M., Nguekouo Foyette C., 1997. Effects of replacement of maize with dried leaves of sweet potato (Ipomoea batatas) and perennial peanuts (Arachis glabrata Benth) on the growth performance of finishing broilers. Anim. Feed Sci. Tech. 66, 283-287

Téguia A., Ørskov E.R., Kyle D.J., 1999. A note on ruminal in silu degradability and in vitro gas production of some West African grass species and multipurpose legume tree leaves. J. Anim Feed Sci. 8, 365-374

Téguia A., Tclıoumboue J., Mayaka B.T., Tankou C.M., 1993. The growth of broiler chickens as affected by the replacement of graded levels of maize by sweet potato leaves (Ipomoea batatas) or Ndole (Vernonia spp.) in the finisher diet. Anim. Feed Sci. Tech. 40, 233-237

USDA, 1984. United States Standards for Quality of Individual Shell Eggs. U.S. Department of Agriculture, Food Safety and Quality Service, Agriculture Handbook

\section{STRESZCZENIE}

\section{Wplyw żywienia zielonkami na produkcję jaj i zabarwienie żóltek u kur nieśnych}

Porównano produkcje jaj i wybarwienic żóttek u kur nicśnych, którym podawano liście Arachis glabarta, Leucaena leucocephala, Calliandra calothyrsus lub Desmodium spp., bądź dietą kontrolną zawierającą barwnik Carophyl@. Nieśność kur żywionych dietą z liśćmi Desmodium spp. i Leucaena leucocephala była istotnie $(\mathrm{P} \leq 0,05)$ większa (odpowiednio $77,4 \mathrm{i} 74,7 \%$ ) niż w grupie kontrolnej. Rodzaj skarmianej diety nie miał wpływu na grubość skorupy jaj. Wybarwienic żółtek było istotnic $(\mathrm{P} \leq 0,05)$ lepsze w grupach żywionych micszanką z dodatkien zielonek niż w grupie kontrolnej $(6,76-9,83$ vs 2,35$)$. Wydaje się, że wszystkie badane zielonki mogą być używane jako źródło barwnika dla kur nieśnych bez ujemnego wpływu na produkcję i jakość jaj. 